University of Nebraska - Lincoln

DigitalCommons@University of Nebraska - Lincoln

Publications, Agencies and Staff of the U.S.

Department of Commerce

U.S. Department of Commerce

2003

\title{
Trends in the Benthic Macroinvertebrate Community of Saginaw Bay, Lake Huron, 1987 to 1996: Responses to Phosphorus Abatement and the Zebra Mussel, Dreissena polymorpha
}

\author{
Thomas F. Nalepa \\ Great Lakes Environmental Research Laboratory, thomas.nalepa@noaa.gov \\ David L. Fanslow \\ Great Lakes Environmental Research Laboratory \\ Margaret B. Lansing \\ Great Lakes Environmental Research Laboratory \\ Gregory A. Lang \\ Great Lakes Environmental Research Laboratory
}

Follow this and additional works at: https://digitalcommons.unl.edu/usdeptcommercepub

Part of the Environmental Sciences Commons

Nalepa, Thomas F.; Fanslow, David L.; Lansing, Margaret B.; and Lang, Gregory A., "Trends in the Benthic Macroinvertebrate Community of Saginaw Bay, Lake Huron, 1987 to 1996: Responses to Phosphorus Abatement and the Zebra Mussel, Dreissena polymorpha" (2003). Publications, Agencies and Staff of the U.S. Department of Commerce. 398.

https://digitalcommons.unl.edu/usdeptcommercepub/398

This Article is brought to you for free and open access by the U.S. Department of Commerce at DigitalCommons@University of Nebraska - Lincoln. It has been accepted for inclusion in Publications, Agencies and Staff of the U.S. Department of Commerce by an authorized administrator of DigitalCommons@University of Nebraska - Lincoln. 


\title{
Trends in the Benthic Macroinvertebrate Community of Saginaw Bay, Lake Huron, 1987 to 1996: Responses to Phosphorus Abatement and the Zebra Mussel, Dreissena polymorpha
}

\author{
Thomas F. Nalepa*, David L. Fanslow, Margaret B. Lansing, and Gregory A. Lang \\ Great Lakes Environmental Research Laboratory \\ 2205 Commonwealth Blvd. \\ Ann Arbor, Michigan 43105
}

\begin{abstract}
Trends in benthic macroinvertebrate populations were examined in inner and outer Saginaw Bay, Lake Huron, from 1987 to 1996. These years represent the time period after phosphorus abatement, but immediately before (1987 to 1990) and after (1991 to 1996) colonization of the bay by the zebra mussel, Dreissena polymorpha. In 1987 to 1990, densities of the major macroinvertebrate groups in the inner and outer bay were not significantly different from, or were greater than, densities reported just prior to abatement efforts in the early 1970s. Oligochaete densities in the deepwater/silt region of the inner bay were trending downward between 1988 and 1991, but pollution-tolerant forms dominated the community, indicating the system was eutrophic just prior to Dreissena colonization. Dreissena impacts on the macroinvertebrate community varied depending on the particular habitat. At shallow-water/sand sites in the inner bay, Gammarus increased, and sphaeriids declined after Dreissena colonization, but no changes were observed in oligochaetes and chironomids, and overall species diversity showed little change. At deepwater/silt sites in the inner bay, densities of oligochaetes and chironomids declined just after the peak in Dreissena, but then returned to levels generally similar to those found prior to Dreissena. The oligochaete trophic index at deepwater/silt sites indicated a shift from eutrophic to more oligotrophic indicator species after Dreissena became established, and species diversity increased. In the outer bay, Diporeia and sphaeriids declined after Dreissena peaked, but few other changes were observed. Total non-dreissenid macroinvertebrate biomass (AFDW) in the inner bay, and in shallow areas of the outer bay, did not change as a result of Dreissena colonization. On the other hand, biomass in the deeper regions of the outer bay decreased because of the loss of Diporeia. Changes in the inner and outer bay typify the growing dichotomy between nearshore and offshore communities in the Great Lakes since Dreissena became established.
\end{abstract}

INDEX WORDS: Benthos, community changes, ecological impacts, Saginaw Bay.

\section{INTRODUCTION}

Prior to the introduction of the dreissenid mussels Dreissena polymorpha and Dreissena bugensis (zebra mussel and quagga mussel), broad-scale trends in benthic macroinvertebrate communities in nearshore areas of the Great Lakes $(<30 \mathrm{~m}$, shallow bays and basins) were mainly attributed to changes in nutrient loads. Increased inputs of phosphorus up until the mid-1970s led to increased densities of benthic taxa that were tolerant of eutrophic-polluted conditions, while densities of less-tolerant taxa declined (see Cook and Johnson 1974 for review).

*Corresponding author. E-mail: Thomas.Nalepa@noaa.gov
After phosphorus abatement programs in the mid1970s, abundances generally declined, and communities in many nearshore areas shifted back to taxa more indicative of an improved trophic state (Johnson and McNeil 1986, Kreiger and Ross 1993, Schloesser et al. 1995, Kilgour et al. 2000).

The introduction and proliferation of dreissenid mussels has complicated the interpretation of benthic community trends relative to changes in nutrient loads and system productivity. Because of large standing stocks and high filtering rates, dreissenids have altered normal pathways of energy flow from pelagic to benthic regions (Nalepa and Fahnenstiel 1995), or have physically altered benthic habitats (Bially and MacIsaac 2000). Impacts on the 
macroinvertebrate community have varied depending upon particular habitat, spatial proximity to mussel colonies, and taxa initially present. In nearshore, hard-substrate regions, abundances of many taxa have increased in response to the increase in habitat complexity created by mussel colonies, and/or to the increase in food availability from mussel biodeposits (Wisenden and Bailey 1995, Botts et al. 1996, Howell et al. 1996, Ricciardi et al. 1997). In deeper, offshore regions, the response has generally led to a decline in abundances, likely because mussels in nearshore areas sequester food resources that normally would settle in depositional zones (Nalepa et al. 1998, Lozano et al. 2001). Other studies have shown no change in benthic standing stocks after Dreissena colonization (Johannsson et al. 2000), or the positive response for many taxa was short term, even in hard-substrate, nearshore regions (Haynes et al. 1999).

In this paper, we document trends in benthic macroinvertebrate populations in Saginaw Bay, Lake Huron between 1987 and 1996, and these trends are examined relative to both phosphorus abatement and the establishment of Dreissena. When the sampling surveys were initiated in 1987 and 1988, the objective was to determine if the benthic community in the bay had responded to improvements in water quality that resulted from reductions in phosphorus loads (Bierman et al. 1984). Sampling was designed to assess changes since the early 1970s, which was the time period just before abatement efforts. When Dreissena became established in Lake St. Clair and rapidly spread through Lake Erie in 1988, it was reasoned that this species would soon become very abundant in Saginaw Bay, and further benthic sampling was initiated in 1990 and continued through 1996 with the objective of assessing changes induced by Dreissena. Dreissena did become established in the bay in 1991 (Nalepa et al. 1995), and thus the 1987 to 1996 sampling period represents the years immediately before and after dreissenid colonization.

\section{DESCRIPTION OF STUDY SITE}

Saginaw Bay is a shallow, well-mixed extension of the western shoreline of Lake Huron (Fig. 1). The bay is 21 to $42 \mathrm{~km}$ wide, about $82 \mathrm{~km}$ long, and has a drainage basin of about $21,000 \mathrm{~km}^{2}$. Total area of the bay is $2.77 \times 10^{9} \mathrm{~m}^{2}$, and total water volume is $24.54 \times 10^{9} \mathrm{~m}^{3}$. The bay can be functionally divided into an inner and outer region by a line extending along its narrowest width $(21 \mathrm{~km})$ from
Sand Point to Point Lookout (Fig. 1). A broad shoal and several islands (Charity Islands) near this line provide a natural demarcation between the two regions. Differences in physical and chemical features of the inner and outer bay regions are distinct (Beeton et al. 1967, Smith et al. 1977). The inner bay has a mean depth of $5.1 \mathrm{~m}$ (maximum $14 \mathrm{~m}$ ), is nutrient-rich, and is heavily influenced by organic inputs from the Saginaw River; the river accounts for over $70 \%$ of the total tributary flow into the bay. The outer bay has a mean depth of $13.7 \mathrm{~m}$ and is more influenced by the colder, nutrient-poor waters of Lake Huron. The inner bay is well-mixed, but thermal stratification is occasionally observed in deeper water (> $10 \mathrm{~m}$ ) (Nalepa et al. 1996).

Circulation within the inner and outer bay is generally weak; currents average about $7 \mathrm{~cm} / \mathrm{s}$ in the inner bay and about $11 \mathrm{~cm} / \mathrm{s}$ in the outer bay (Danek and Saylor 1977). Exchange and flushing of water in the inner and outer bay occurs mainly when winds blow along the long axis of the bay (southwest/northeast). Most water exchange occurs on the northern side of the bay within the deep channel that occurs between Point Lookout and Charity Island. Although some water may exit the inner bay along the southern shoreline, it is of minor significance because of the shallowness of the region (Danek and Saylor 1977).

Bottom substrates within the bay range from mostly cobble/rock to silt. The inner bay has a shallow sand bar that extends along the southeastern side of the bay from the Saginaw River to Charity Island. Another sand bar extends along the northwestern shoreline to Point Au Gres. Both sand bars have irregular areas of cobble with patches of gravel, pebbles, and varying amounts of overlying silt. The bars extend into the shorelines as extensive flats grade to marshes. Water depth between the two sand bars gradually increases to a maximum of 14 $\mathrm{m}$ (Fig. 1). The proportion of fine-grained material gradually increases along this depth gradient as a function of sediment deposition (Robbins 1981). At depths greater than $6 \mathrm{~m}$, the substrate consists of fine-grained material (silt and clay) and sediment deposition ranges from 0.04 to $0.70 \mathrm{~g} / \mathrm{cm}^{2} / \mathrm{yr}$ (Robbins 1981).

In the outer bay, the east shore is rocky, as is the area around Charity Island (Fig 1). The western shore has extensive sandy areas, with rock and clay found near Point Lookout. With increased depth, the substrate is mostly sand with varying amounts of overlying silt. 




FIG. 1. Location of sampling sites in Saginaw Bay, 1987 to 1996. Dashed line separates the inner bay from the outer bay. Depth contours are given in meters. $\bullet=$ sampled in 1987 and 1988 only; Osampled in 1987-1996; $X=$ sampled in 1991-96 for Dreissena using $S C U B A$ divers.

\section{MATERIALS AND METHODS}

\section{Dates, Locations, and Procedures}

Samples for benthic macroinvertebrates were collected at 30 sites in 1987 and 1988, and at 10 sites in 1990 to 1996 (Fig. 1). Samples were collected in spring (May), summer (July), and fall (Sept. to Nov.) of each year except in 1996 when samples were collected only in summer and fall. Because of poor weather or mechanical failures, not all sites were sampled on some dates. Site locations and sampling dates are given in Nalepa et al. (2002). Sampling sites were selected by first plotting site locations of previous benthic surveys (Surber 1954, 1955; Schneider et al. 1969; Batchelder 1973; Great 
Lakes Research Division, University of Michigan, unpublished data), and then choosing the sites to resample based on type of sampler used, detail of data provided, and spatial coverage of the bay.

Triplicate samples were collected at each site with a Ponar grab $\left(\right.$ area $\left.=0.046 \mathrm{~m}^{2}\right)$. After collection, each sample was washed into a large tub, and then into an elutriation device fitted with a sleeve made of 0.5-mm mesh Nitex (Nalepa et al. 1985). Retained material was washed into a collection jar and preserved in 5\% buffered formalin containing rose bengal stain. The substrate was visually described prior to rinsing the sample through the Nitex screen (Nalepa et al. 1985).

To obtain quantitative estimates of Dreissena, samples were collected at eight sites using SCUBA divers every fall from 1991 to 1996 (Fig. 1). Five sites were located in areas with sand/cobble and could not be effectively sampled with the Ponar (Stations 5, 6, 15, 19, 27), while three sites had sand substrates and were sampled by both SCUBA and Ponar (Stations 13, 14, 16). At each site, divers randomly placed a 0.25 or $0.5 \mathrm{~m}^{2}$ frame on the bottom and hand-collected all hard material within the frame area. After all material was removed, the area within the frame was re-sampled using a diveroperated suction device fitted with a Nitex net with 0.5-mm openings (Winnell and Jude 1987). This procedure ensured that all loose mussels were included in the sample. Triplicate samples were collected at each site, with divers moving 2 to $3 \mathrm{~m}$ between replicates.

In the laboratory, material collected in the grab and retained by the $0.5-\mathrm{mm}$ sleeve was placed into a white enamel pan and organisms were removed, enumerated, and sorted into major groups (Amphipoda, Oligochaeta, Sphaeriidae, Chironomidae, Dreissena, and others) under a $1.5 \times$ lighted magnifier lamp. Turbellarians and nematodes were observed in the samples but, since methods were not quantitative for these groups, their numbers were not recorded. When the number of organisms in a sample was extremely large, the sample was proportionately split and only a portion was processed. All organisms were identified to the lowest practical taxonomic level. For oligochaetes, between 75 and 100 individuals in a replicate (proportionately split with a Folsom plankton splitter when numbers were high) were cleared in lactophenol before identification. Oligochaetes were mounted on microscope slides (in glycerine) and their images were projected onto a sheet of paper using a camera lucida and then traced. Individuals were identified, and taxonomic designations placed alongside the respective traced image. Only individuals with a prostomium were identified and tabulated; fragments (without prostomium) were identified as such but were not counted. For chironomids, a maximum of 50 individuals were identified per replicate. Head capsules were teased off the body, cleared in lactophenol, and mounted on microscope slides with mentum side up. The corresponding body was mounted alongside the head capsule and the image traced as for oligochaetes.

Biomass (ash-free dry weight [AFDW]) for Amphipoda, Isopoda, Ephemeroptera, Oligochaeta, Chironomidae, and Dreissena were derived from length-weight relationships determined either directly on fresh animals, or taken from the literature. If a length-weight relationship for a given taxon was not available from the literature, it was assigned the relationship of a closely-related form (Nalepa et al. 2002). When length-weight relationships were available for only dry weight, ash-free dry weight was assumed to be $90 \%$ of dry weight (Johnson and Brinkhurst 1971). Weights were determined by placing fresh animals into pre-weighted, aluminum planchets, dried at $60^{\circ} \mathrm{C}$ for $48 \mathrm{~h}$, and weighed to the nearest $0.1 \mathrm{mg}$. AFDW was obtained by re-weighing the specimens after ashing at $550^{\circ} \mathrm{C}$ for $1 \mathrm{~h}$. Lengths were measured directly or determined from traced images using a digitizer (Quigley and Lang 1989).

For oligochaetes, all body fragments present on the slides were measured and included in the biomass total. Length-weight conversions are based on the finding that preservation does not alter length (Erman and Erman 1975). For Dreissena, lengths were measured on up to 500 animals in each sample using a computer scanner and fitted software. If more individuals were present in the sample, the sample was proportionately split. To determine length-weight of Dreissena, at least 25 individuals of various sizes were collected in fall at Station 5 in 1991 to 1996 , and at Station 19 in 1994 to 1996. Annual biomass is best derived from a lengthweight determined in the fall when spawning has been completed (Nalepa et al. 1993). Shell lengths were measured, and AFDW of the soft tissue was determined as above. Corresponding length-weight relationships were determined and then used to calculate soft-tissue biomass of mussels at the various sites. In 1991 to 1993, length-weight relationships derived from mussels collected at Station 5 were used to calculate biomass at all sites, but in 1994 to 1996 separate relationships derived from mussels at 
TABLE 1. Mean density (no./ $\mathrm{m}^{2} \pm S E$ ) of major benthic macroinvertebrate groups in 1987/88. Stations in the inner bay were grouped by substrate (I, II, III), and stations in the outer bay were grouped by depth (IV, V, VI). Differences between the substrate/depth groups for the inner and outer bay were tested for each macroinvertebrate group using ANOVA (ln +1 transformed $)$. ns = not significantly different.

\begin{tabular}{|c|c|c|c|c|c|c|c|c|}
\hline Group & Station & $\begin{array}{l}\text { Depth } \\
\text { (m) }\end{array}$ & Substrate & Oligochaeta & Chironomidae & Amphipoda & Sphaeriidae & Total \\
\hline \multicolumn{9}{|l|}{ Inner Bay } \\
\hline I & $\begin{array}{c}13,14 \\
16,18,28\end{array}$ & $3.0-4.8$ & sand/gravel & $1,111 \pm 281$ & $202 \pm 94$ & $60 \pm 21$ & $58 \pm 19$ & $1,441 \pm 374$ \\
\hline II & $\begin{array}{c}2,11,22 \\
25,30,35 \\
58,68,108\end{array}$ & $4.2-9.0$ & silty sand & $5,870 \pm 808$ & $2,163 \pm 801$ & $15 \pm 7$ & $250 \pm 49$ & $8,327 \pm 1,281$ \\
\hline III & $\begin{array}{c}4,7,10 \\
26,168,278\end{array}$ & $6.7-11.8$ & silt & $\begin{array}{c}20,954 \pm 1,909 \\
P<0.01\end{array}$ & $\begin{array}{c}1,412 \pm 159 \\
P<0.01\end{array}$ & $\begin{array}{l}<1 \pm<1 \\
\mathrm{P}<0.01\end{array}$ & $\begin{array}{l}86 \pm 19 \\
P<0.01\end{array}$ & $\begin{array}{c}21,951 \pm 2,019 \\
P<0.01\end{array}$ \\
\hline $\begin{array}{l}\text { Outer Bay } \\
\text { IV }\end{array}$ & $24,43,57$ & $10-13$ & silty sand & $4,952 \pm 659$ & $4,559 \pm 439$ & $117 \pm 5$ & $385 \pm 298$ & $10,025 \pm 84$ \\
\hline V & $20,45,53,55$ & $16-22$ & silty sand & $3,043 \pm 300$ & $1,010 \pm 282$ & $93 \pm 39$ & $189 \pm 72$ & $4,337 \pm 306$ \\
\hline VI & 23,50 & $28-30$ & silty sand & $\begin{array}{c}2,304 \pm 1,094 \\
n s\end{array}$ & $\begin{array}{l}191 \pm 44 \\
P<0.01\end{array}$ & $\begin{array}{c}1,209 \pm 254 \\
P<0.05\end{array}$ & $\begin{array}{c}222 \pm 45 \\
n s\end{array}$ & $\begin{array}{c}3,982 \pm 1,159 \\
P<0.01\end{array}$ \\
\hline
\end{tabular}

Station 5 and Station 19 were used to calculate biomass at sites in the inner bay and outer bay, respectively.

AFDW of other benthic taxa (Sphaeriidae, Gastropoda, Trichoptera, Isopoda, Hirudinea, and Diptera other than Chironomidae) was determined directly from preserved specimens within a given sample. While preservation does not cause weight loss in Sphaeriidae (Johnson and Brinkhurst 1971), weight loss likely occurred in the other taxa. However, these taxa generally constituted only a small portion of total biomass at a given site. Further details of biomass determinations, including lengthweight regressions, are given in Nalepa et al. (2002).

\section{Site Groupings and Analysis}

To examine benthic responses to abatement efforts, data collected in 1987 to 1990 (post abatement and pre-Dreissena) were compared to data from two surveys conducted in the early 1970s (preabatement). One survey occurred mainly in the inner bay (in 1971; Batchelder 1973), and the other occurred in the outer bay (in 1972; Great Lakes Research Division [GLRD], University of Michigan, unpublished data). Sampling methods in both sur- veys were similar to that of this study; that is, the collection device was the Ponar grab, and samples were washed through a 500-600- $\mu$ m screen. We matched our sites with sites sampled in 1971 based on substrate, water depth, and general location, while our site locations matched 1972 site locations exactly since the 1972 coordinates were incorporated into the original sampling design. When testing for differences between the two time periods within a given substrate, each site pairing was considered a separate replicate.

Substrates at the twenty-one sites sampled with the Ponar grab in the inner bay varied from coarse sand/gravel to silt, and water depths ranged from 3.0 to $11.8 \mathrm{~m}$ (Nalepa et al. 2002). As found by others (Wood 1964, Robbins 1981), the amount of finegrained material increased with water depth. For purposes of data analysis, sites in the inner bay were grouped into three categories based on water depth and substrate type: 1) sand/gravel, 3.0 to $4.8 \mathrm{~m}$; 2) silty sand, 4.2 to $9.0 \mathrm{~m}$; and 3) silt, 6.7 to $11.8 \mathrm{~m}$ (Table 1). The only site that did not fit into one of these categories was Station 31. Water depth at this site was only $3.2 \mathrm{~m}$, but the substrate differed from all other sites, consisting of coarse plant debris/silt. This site was located in the center of a shallow, confined embayment (Wildfowl Bay) and 
was not representative of the bay in general. With this exception, sites in these three categories were located in regions considered to be non-depositional, transitional, and depositional, respectively (Robbins 1981). In the outer bay, substrates consisted of silty sand at all sites, and depths ranged from 10 to $30 \mathrm{~m}$ (Nalepa et al. 2002). Since substrates were generally the same, the nine outer bay sites were grouped into three categories based on water depth: 10 to $13 \mathrm{~m}, 16$ to $22 \mathrm{~m}$, and 28 to $30 \mathrm{~m}$ (Table 1). These depth categories are consistent with prior characterization of depth-macroinvertebrate associations in other regions of the Great Lakes for similar depths and substrate types (Cook and Johnson 1974, Mozley and Howmiller 1977).

As noted, only ten sites were sampled in 1990 to 1996, but these sites were considered to be representative of the various habitat types. In the inner bay, three sites were in the shallow water/sand region (Stations 13, 14, 16), one site was in the middepth/silty sand region (Station 11), and three sites were in the deep water/silt region (Stations 4, 7, and 10) (Fig. 1). In the outer bay, sampling was continued at three sites, each within the three depth intervals: $13 \mathrm{~m}$ (Station 24), $16 \mathrm{~m}$ (Station 20), and 28 m (Station 23).

When testing for benthic macroinvertebrate responses to Dreissena colonization, the 1987 to 1990 period was considered as the pre-Dreissena period, and 1993 to 1996 was considered as the post-Dreissena period. While data collected in 1991 and 1992 were included when interpreting trends, these 2 years were considered transitional and not included in the statistical analysis. That is, Dreissena was present for only part of the year in 1991, and abundances were at unsustainably high levels in 1992 (Nalepa et al. 1995). Only data collected at the ten sites sampled every year were used to assess Dreissena impacts. The mean of each year was considered an individual replicate, and differences between periods were tested using a t-test. Abundance data were $\ln +1$ transformed prior to any statistical analysis (t-tests and ANOVAs) and met the requirements of normality and equality of variances.

Species composition of the oligochaete community is a good indicator of trophic status, and community changes were examined using an oligochaete trophic index (Howmiller and Scott 1977, Milbrink 1983, Lauritsen et al. 1985). The index is determined by placing each species (excluding Naididae and Enchytraeidae) into one of four categories based on its tolerance to organic en- richment. Values of each category range from 0 (intolerant of enrichment; found mostly in oligotrophic conditions) to 3 (tolerant of enrichment; found in highly eutrophic conditions). The assigned category of each species follows that of Milbrink (1983) and Lauritsen et al. (1985). To obtain the index, the number of individuals in each category is multiplied by the category value (species in category 0 are assigned a value of 0.5 ). The products are then summed and divided by the total number of individuals.

The Simpson Diversity Index (Simpson 1949) and the Bray Curtis Index (Bray and Curtis 1957) were used to determine changes in structure of the entire macroinvertebrate community. The former index considers both taxonomic richness and evenness, while the latter considers presence/absence and absolute abundance of each taxa. Of the many similarity indices, the Bray-Curtis Index has been shown to be the most effective quantitative index when assessing changes in community structure (Hruby 1987, Pontasch and Brusven 1988, Pontasch et al. 1989). Since the index is sensitive to occasional large numbers, data were square-root transformed prior to index calculation (Pontasch and Brusven 1988). Both indices were determined on the non-dreissenid community.

\section{RESULTS}

\section{General Distribution Patterns in 1987 and 1988}

Since 30 sites were sampled in 1987 and 1988 and these sites provided broad spatial coverage of the bay, data collected in these 2 years were used to characterize general distribution patterns. Total mean densities in the inner bay generally increased with water depth and the amount of fine-grained material (Table 1, Fig. 2). Mean densities at sites with sand, silty sand, and silt substrates were 1,441, 8,327 , and $21,951 / \mathrm{m}^{2}$, respectively. Differences were significant for all major macroinvertebrate groups (ANOVA, $\mathrm{P}<0.01$ ) (Table 1). Oligochaetes, chironomids, and sphaeriids were more abundant at sites with sandy silt or silt substrate, while the amphipod Gammarus sp. was most abundant at sites with sand. In terms of composition, oligochaetes were the dominant group in all three substrates, accounting for 77 to $95 \%$ of all organisms collected. Dominant species in silt were Limnodrilus hoffmeisteri and Limnodrilus cervix, while the naidids Piguetiella michiganensis, Uncinais uncinata, and Arcteonais lomondi were the most common species in sand. Most abundant chironomid species 


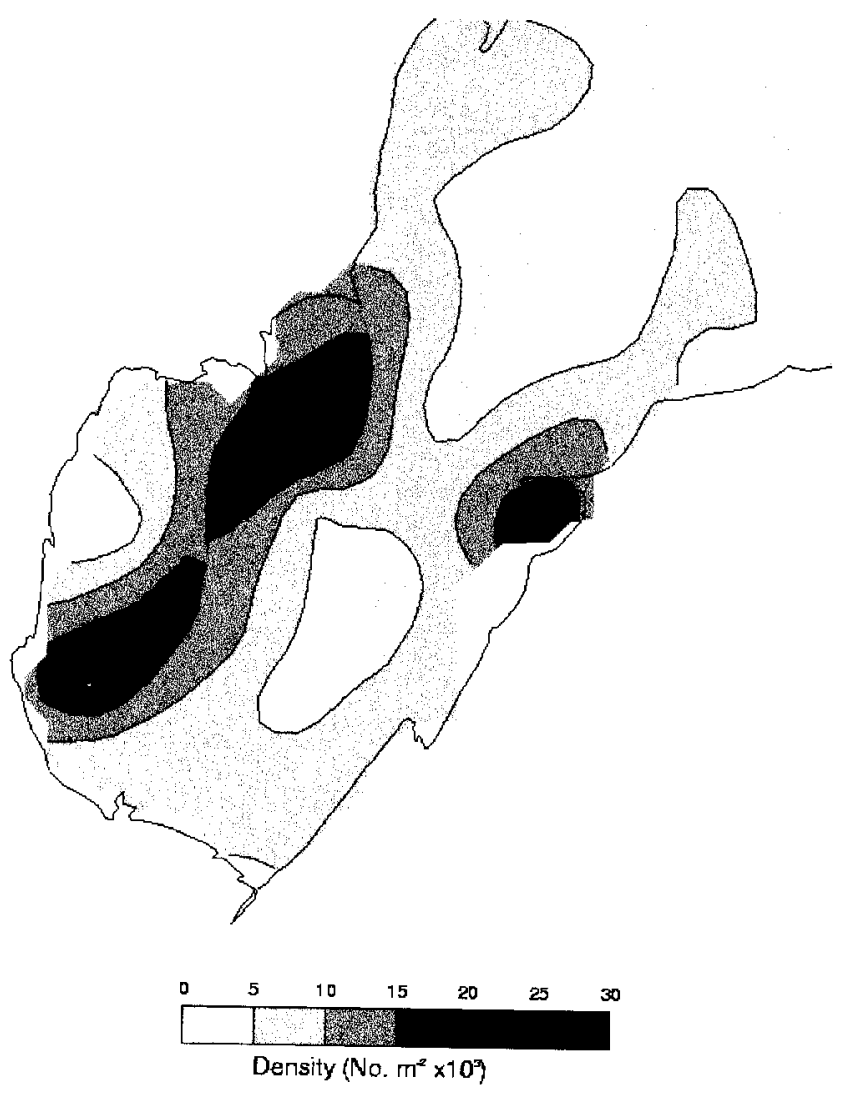

FIG. 2. Mean total density $\left(n o . / m^{2} \times 10^{3}\right)$ of benthic macroinvertebrates in Saginaw Bay, 1987 and 1988.

were Cladotanytarsus spp. and Tanytarsus sp. in sand, Chironomus anthracinus, Tanytarsus sp., and Procladius sp. in silty sand, and Chironomus semireductus-gr. and $C$. anthracinus in silt.

In the outer bay, total density declined, and the community shifted to species more typical of a cold-water environment as depth increased. The greatest depth-related change occurred in chironomids (Table 1). Chironomid densities declined from $4,559 / \mathrm{m}^{2}$ at the 10 to $13 \mathrm{~m}$ interval to $191 / \mathrm{m}^{2}$ at the 28 to $30 \mathrm{~m}$ interval $(\mathrm{P}<0.01)$. Tanytarsus sp., Paratendipes sp., and C. anthracinus were the dominant taxa at the shallower sites, while Heterotrissocladius spp. was dominant at the deeper sites. The amphipod Diporeia spp. was most abundant at the deepest interval $(\mathrm{P}<0.01)$. Both Heterotrissocladius and Diporeia are typically found in the colder, deeper regions of the Great Lakes; both species were rarely found in the inner bay. Total densities of both oligochaetes and sphaeriids were not related to depth $(\mathrm{P}>0.05)$. At least for the former group, this was partly attributable to high densities at one of the sites in the deepest interval, Station 50. Mean oligochaete density at this site was $4,100 / \mathrm{m}^{2}$, compared to just $430 / \mathrm{m}^{2}$ at the other site within this interval, Station 23. This difference could be attributed to high numbers of tubificids at Station 50 (82\% of all oligochaetes), of which Potamothrix vejdovskyi and $L$. hoffmeisteri were the dominant species. Based on typical exchange rates and flow patterns from the inner bay to the outer bay (Danek and Saylor 1977), the community at Station 50 was more likely influenced by nutrient-rich waters from the inner bay than the community at Station 23 . Both chlorophyll and total suspended matter was consistently higher at the former station compared to the latter (Nalepa et al. 1996). Both P. vejdovskyi and L. hoffmeisteri do well in enriched environments (Milbrink 1983). In contrast, the dominant oligochaete species at Stations 23 was Stylodrilus heringinaus, an oligotrophic, cold-water form.

\section{Comparisons Pre- and Post-Phosphorus Abatement}

A total of twelve sites sampled in the inner bay in 1987 to 1990 (post abatement) were matched with sites sampled in 1971 by Batchelder (1973) (preabatement). Comparisons of the major benthic groups indicated that mean densities in 1987 to 1990 were generally similar to, or greater than, densities in 1971 (Table 2). In terms of species composition, only the chironomid community could be compared since oligochaetes were not identified to species in 1971. Further, only broad, generic comparison of the chironomid community was possible because of uncertainties with nomenclature and level of taxonomic detail given for the 1971 data. Dominant chironomid taxa in 1971 were Tanytarsus sp. (50\%) and Polypedilum spp. (31\%) in sand, Chironomus spp. (41\%) and Procladius spp. (34\%) in silty sand, and Chironomus spp. (93\%) in silt (Batchelder 1973). For the same sites, dominant species in 1987 to 1990 were Cladotanytarus spp. (25\%) and Tanytarsus sp. (23\%) in sand, Chironomus spp. (47\%), Tanytarsus sp. (30\%) and Procladius sp. (12\%) in silty sand, and Chironomus spp. $(95 \%)$ in silt.

In the outer bay, five of the sites sampled in 1987 to 1990 corresponded to sites that were sampled in 1972 (Table 3). A comparison of densities in the two sampling periods indicated that all differences in the major groups were non signifi- 
TABLE 2. Mean densities (no./m²) of major benthic macroinvertebrate groups in 1971 and 1987 to 1990 in inner Saginaw Bay by substrate type. The 1971 data were taken from Batchelder (1973). Stations sampled in the two time periods were paired based on general station location, water depth, and substrate type. Station designations of Batchelder (1973) are given in parenthesis. Density differences between periods were tested for each substrate type using paired t-test after In +1 transformation with each site pairing considered a replicate. Station 31 was not included in the analysis (see text). * = significantly different at $P<0.05$.

\begin{tabular}{|c|c|c|c|c|c|c|c|c|}
\hline \multirow{2}{*}{$\begin{array}{l}\text { Substrate/ } \\
\text { Station }\end{array}$} & \multicolumn{2}{|c|}{ Oligochaeta } & \multicolumn{2}{|c|}{ Chironomidae } & \multicolumn{2}{|c|}{ Amphipoda } & \multicolumn{2}{|c|}{ Sphaeriidae } \\
\hline & 1971 & 1987-90 & 1971 & 1987-90 & 1971 & $1987-90$ & 1971 & $1987-90$ \\
\hline \multicolumn{9}{|l|}{ Sand } \\
\hline $13(29)$ & 1,587 & 908 & 570 & 136 & 215 & 104 & 43 & 27 \\
\hline $14(24)$ & 1,033 & 516 & 323 & 140 & 215 & 38 & 0 & 33 \\
\hline $18(21)$ & 1,689 & 2,168 & 1,700 & 524 & 0 & 5 & 0 & 136 \\
\hline Mean & 1,436 & 1,197 & 764 & $267^{*}$ & 143 & 49 & 14 & 65 \\
\hline$\pm \mathrm{SE}$ & \pm 204 & \pm 498 & \pm 493 & \pm 129 & \pm 72 & \pm 29 & \pm 14 & \pm 35 \\
\hline \multicolumn{9}{|l|}{ Silty Sand } \\
\hline $2(20)$ & 10,706 & 6,696 & 1,452 & 2,626 & 0 & 8 & 0 & 74 \\
\hline $30(30)$ & 8,619 & 10,230 & 624 & 2,157 & 0 & 8 & 0 & 343 \\
\hline $11(32)$ & 2,303 & 6,799 & 554 & 6,941 & 0 & 6 & 0 & 535 \\
\hline $108(25)$ & 4,100 & 5,269 & 484 & 1,510 & 0 & 2 & 0 & 60 \\
\hline Mean & 6,432 & 7,249 & 779 & $3,309 *$ & 0 & $6^{*}$ & 0 & $253 *$ \\
\hline$\pm \mathrm{SE}$ & $\pm 1,948$ & $\pm 1,053$ & \pm 226 & $\pm 1,232$ & \pm 0 & $\pm<1$ & \pm 0 & \pm 114 \\
\hline \multicolumn{9}{|l|}{ Silt } \\
\hline $4(18)$ & 14,956 & 22,380 & 1,668 & 1,790 & 0 & 0 & 0 & 86 \\
\hline $7(22)$ & 12,008 & 15,299 & 2,216 & 1,338 & 0 & 1 & 0 & 141 \\
\hline $10(28)$ & 16,151 & 18,582 & 4,541 & 1,307 & 22 & 1 & 0 & 53 \\
\hline $168(23)$ & 11,534 & 13,313 & 1,571 & 749 & 0 & 2 & 43 & 7 \\
\hline Mean & 13,662 & $17,394 *$ & 2,499 & 1,296 & 6 & 1 & 11 & 72 \\
\hline$\pm \mathrm{SE}$ & $\pm 1,123$ & $\pm 1,986$ & \pm 602 & \pm 213 & \pm 5 & $\pm<1$ & \pm 11 & \pm 28 \\
\hline \multirow{2}{*}{\multicolumn{9}{|c|}{$\begin{array}{l}\text { Silt: } \\
\text { Wildfowl Bay }\end{array}$}} \\
\hline & & & & & & & & \\
\hline $31(31)$ & 4,882 & 19,337 & 1,799 & 1,746 & 0 & 44 & 0 & 0 \\
\hline
\end{tabular}

cant (paired t-test, $\mathrm{P}>0.05$ ). Further, the oligochaete trophic index indicated the community was dominated by oligotrophic species in both time periods. Index values (mean \pm SE) were $0.96 \pm$ 0.05 in 1972 and $1.02 \pm 0.02$ in 1987-90. Dominant species were Spirosperma ferox, Aulodrilus pluriseta, and $S$. heringianus; these three species accounted for $92 \%$ of all oligochaetes in 1972 and $65 \%$ in 1987 to 1990 . Other abundant species in the latter period were P. vejdovskyi (10\%), L. hofmeisteri (6\%), and Aulodrilus americanus (3\%). For chironomids, Tanytarsus sp. was the dominant species in both periods ( $45 \%$ of all chironomids). Differences in Simpson's Diversity Index between the two periods were non-significant (paired t-test, $\mathrm{P}>0.05)$.

\section{Trends and Comparisons, Pre- and Post-Dreissena}

Dreissena was initially found in samples from spring 1991, and the first large recruitment occurred that summer (Nalepa et al. 1995). Mean densities on cobble/sand in the inner bay, as sampled by divers, reached a maximum of $33,838 / \mathrm{m}^{2}$ in 1992 , declined in 1993, and then varied between 2,100 and $5,500 / \mathrm{m}^{2}$ from 1993 to 1996 (Table 4). Few mussels were found at sites with silty sand or silt substrate during the entire sampling period. Densities tended to be higher in the outer bay than in the inner bay, but this was likely a result of greater amounts of hard substrate (cobble, bedrock) found at the outer bay sites. Mean biomass for 1993 to 1996 varied between 4.1 and $13.4 \mathrm{~g} / \mathrm{m}^{2}$ in the inner bay, and between 13.8 and $97.8 \mathrm{~g} / \mathrm{m}^{2}$ in the outer bay (Table 4). Greater biomass occurred at sites in 
TABLE 3. Mean densities (no./m²) of major benthic macroinvertebrate groups in 1972 and 1987 to 1990 in outer Saginaw Bay. The 1972 data were provided by the Great Lakes Research Division, University of Michigan (GLRD unpublished). Station coordinates were similar for the two sampling periods. Station designations in 1972 are given in parenthesis. Mean differences between the two time periods were tested using paired t-test after ln +1 transformation $(n=5)$. All differences were non-significant $(P>0.05)$.

\begin{tabular}{|c|c|c|c|c|c|c|c|c|c|}
\hline \multirow[b]{2}{*}{ Station } & \multirow[b]{2}{*}{ Depth (m) } & \multicolumn{2}{|c|}{ Oligochaeta } & \multicolumn{2}{|c|}{ Chironomidae } & \multicolumn{2}{|c|}{ Amphipoda } & \multicolumn{2}{|c|}{ Sphaeriidae } \\
\hline & & 1972 & 1987-90 & 1972 & 1987-90 & 1972 & $1987-90$ & 1972 & 1987-90 \\
\hline$\overline{57(57)}$ & 10 & 5,647 & 5,184 & 981 & 3,366 & 287 & 173 & 688 & 385 \\
\hline $20(62)$ & 16 & 12,849 & 1,894 & 738 & 1,383 & 186 & 3 & 1,226 & 372 \\
\hline $45(63)$ & 18 & 3,841 & 2,949 & 1,820 & 1,609 & 1,712 & 571 & 1,125 & 92 \\
\hline $53(53)$ & 22 & 4,644 & 4,324 & 380 & 380 & 752 & 338 & 72 & 123 \\
\hline \multirow[t]{2}{*}{$55(55)$} & 22 & 3,698 & 3,240 & 344 & 563 & 4,106 & 1,523 & 1,003 & 156 \\
\hline & $\begin{array}{l}\text { Mean } \\
\pm \text { SE }\end{array}$ & $\begin{array}{r}6,136 \\
\pm 1,713\end{array}$ & $\begin{array}{l}3,518 \\
\pm 568\end{array}$ & $\begin{array}{r}851 \\
+269\end{array}$ & $\begin{array}{l}1,460 \\
\pm 531\end{array}$ & $\begin{array}{r}1,409 \\
\pm 726\end{array}$ & $\begin{array}{r}522 \\
+267\end{array}$ & $\begin{array}{r}823 \\
+208\end{array}$ & $\begin{array}{r}226 \\
\pm 63\end{array}$ \\
\hline
\end{tabular}

TABLE 4. Mean densities (no. $/ \mathrm{m}^{2} \pm S E$ ) and biomass (g AFDW/m2; in parenthesis) of Dreissena polymorpha on various substrate types in inner and outer Saginaw Bay. Sites with cobble/sand and cobble/bedrock were sampled using SCUBA, and other sites were sampled with a Ponar grab. Biomass estimated only for sites sampled with SCUBA. Densities and biomass estimated in the fall of each year. $n$ = number of stations.

\begin{tabular}{|c|c|c|c|c|c|c|c|}
\hline $\begin{array}{l}\text { Location/ } \\
\text { Substrate }\end{array}$ & $\begin{array}{c}\text { Year } \\
\mathrm{n}\end{array}$ & 1991 & 1992 & 1993 & 1994 & 1995 & 1996 \\
\hline \multicolumn{8}{|l|}{ Inner Bay } \\
\hline Cobble/Sand & 6 & $\begin{array}{c}15,210 \pm 8,718 \\
(10.02)\end{array}$ & $\begin{array}{c}33,838 \pm 13,003 \\
(61.87)\end{array}$ & $\begin{array}{c}3,975 \pm 1,312 \\
(4.49)\end{array}$ & $\begin{array}{c}4,982 \pm 1,716 \\
(8.33)\end{array}$ & $\begin{array}{c}2,145 \pm 1,009 \\
(4.09)\end{array}$ & $\begin{array}{c}5,548 \pm 2,663 \\
(13.39)\end{array}$ \\
\hline Silty Sand & 1 & 0 & 45 & 1,268 & 29 & 114 & 18 \\
\hline Silt & 3 & $14 \pm 7$ & $9 \pm 9$ & $37 \pm 26$ & $43 \pm 36$ & $2 \pm 2$ & $7 \pm 7$ \\
\hline \multicolumn{8}{|l|}{ Outer Bay } \\
\hline Bedrock & 2 & $\begin{array}{l}2,944 \pm 464 \\
\quad(0.65)\end{array}$ & $\begin{array}{c}31,168 \pm 26,473 \\
(53.85)\end{array}$ & $\begin{array}{c}4,570 \pm 1,243 \\
(13.79)\end{array}$ & $\begin{array}{c}15,797 \pm 5,872 \\
(44.54)\end{array}$ & $\begin{array}{c}10,800 \pm 6,976 \\
(63.19)\end{array}$ & $\begin{array}{c}13,165 \pm 6,184 \\
(97.76)\end{array}$ \\
\hline Silty Sand & 3 & $0 \pm 0$ & $2 \pm 2$ & $5 \pm 5$ & $0 \pm 0$ & $0 \pm 0$ & $0 \pm 0$ \\
\hline
\end{tabular}

the outer bay not only because of higher densities, but also because the mussels were larger and weighed more per unit length (Nalepa et al. 2002). While mussel densities in the outer bay were generally consistent between 1994 and 1996, biomass increased as a result of an increase in mean size (Nalepa unpublished data).

The response of the benthic community to Dreissena colonization varied depending upon substrate type and water depth. At shallower sites with sand or silty sand substrates in the inner bay, densities of only two taxa changed significantly relative to the establishment of Dreissena (Table 5). At these sites, densities of Gammarus were significantly higher ( $\mathrm{P}$ $<0.05)$, and densities of sphaeriids were significantly lower $(\mathrm{P}<0.05)$ in the post-Dreissena period
(1993 to 1996) compared to the pre-Dreissena period (1987 to 1990). Densities of both oligochaetes and chironomids were not significantly different between the two periods $(\mathrm{P}>0.05)$. Mean annual densities of both groups were highly variable at the site with silty sand (Station 11) in the pre-Dreissena period, which may explain the lack of statistical significance between the pre-and post-Dreissena periods (Table 5). But even so, densities of both groups were relatively stable between 1991 and 1996 and unaffected by the peak and decline in Dreissena over that time period. Since oligochaetes and chironomids, as well as Gammarus, are consistently more abundant in mussel clusters than in surrounding substrates (Karatayev et al. 1997), the relationship between densities of these groups and 


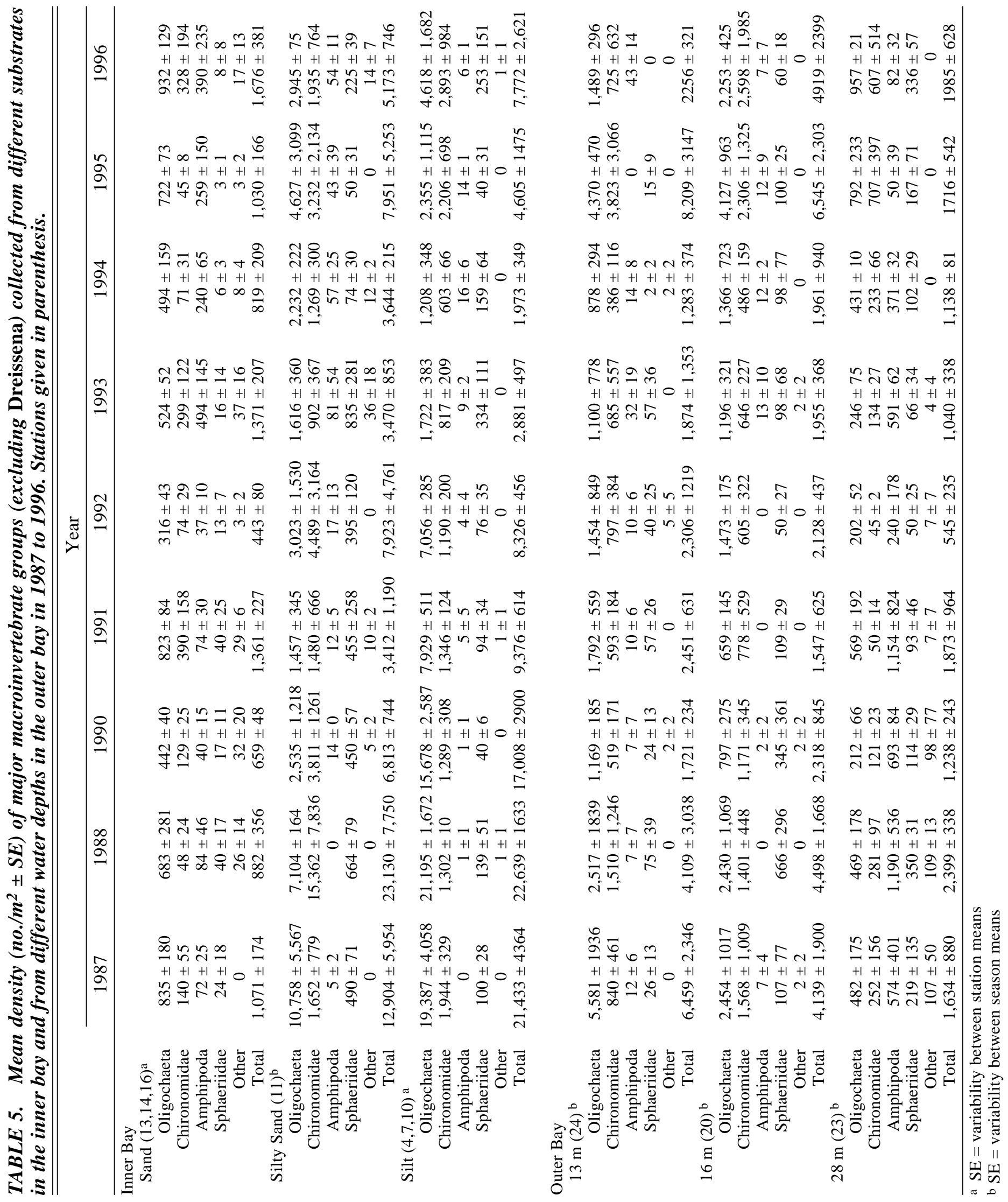


Dreissena was examined by using correlation analysis. Only those replicate samples taken in the post-Dreissena period (1993 to 1996) and with Dreissena present were used in the analysis. Pearson correlation coefficients between densities of oligochaetes and chironomids and Dreissena were not significant $(\mathrm{P}>0.05$; oligochaete coefficient $=$ $0.13, \mathrm{n}=96$; chironomid coefficient $=-0.05, \mathrm{n}=$ 96). In contrast, a similar analysis for Gammarus, was highly significant $(\mathrm{P}<0.01$; coefficient $=0.61$; $\mathrm{n}=62$ ).

Species composition of both oligochaetes and chironomids were generally unaffected by Dreissena at sites with sand and silty sand substrates. The oligochaete trophic index remained generally constant over the entire sampling period at sites with both substrates (Fig. 3a). The index does not include Naididae, however, and this family dominated the oligochaete community at sites with sand. A further examination of naidids indicated some changes in the relative proportion of individual species, although the total number of taxa was similar in the pre-and post-Dreissena periods ( 7 and 10, respectively). The proportion of the following species changed the most between the two periods: Arcteonais lomondi and Chaetogaster sp. decreased ( $14.0 \%$ to $1.2 \% ; 13.6 \%$ to $0.1 \%$ ) and Piguetiella michiganensis increased (40.2\% to $70.0 \%)$. For chironomids, a total of 19 and 24 taxa were collected in the pre- and post-Dreissena periods, respectively, and the dominant species was Cladotanytarsus mancus in both periods (42.8\% and $69.1 \%)$. Temporal trends in Simpson's Diversity Index relative to Dreissena colonization were not apparent (Fig. $3 b)$.

At sites in the deepwater/silt region, oligochaete densities were significantly lower $(\mathrm{P}<0.01)$ in the post-Dreissena period compared to the pre-Dreissena period, but differences in the other groups were not apparent $(\mathrm{P}>0.05)$. Oligochaetes declined from a peak of $21,195 / \mathrm{m}^{2}$ in 1988 to a low of $1,208 / \mathrm{m}^{2}$ in 1994 , and then increased to $4,618 / \mathrm{m}^{2}$ by 1996 . Greatest proportional declines occurred between 1990 and 1991 (50\%), and between 1992 and 1993 (76\%). While the latter decline followed the Dreissena peak, it seems unlikely that the former decline could be attributed entirely to Dreissena. Mean oligochaete density was $17,749 / \mathrm{m}^{2}$ in fall 1990 , but only $7,758 / \mathrm{m}^{2}$ in spring 1991 . Thus, oligochaete densities were already much lower in spring 1991 even before the major Dreissena colonization occurred in summer 1991.

Tubificid oligochaetes comprised $99 \%$ and $90 \%$
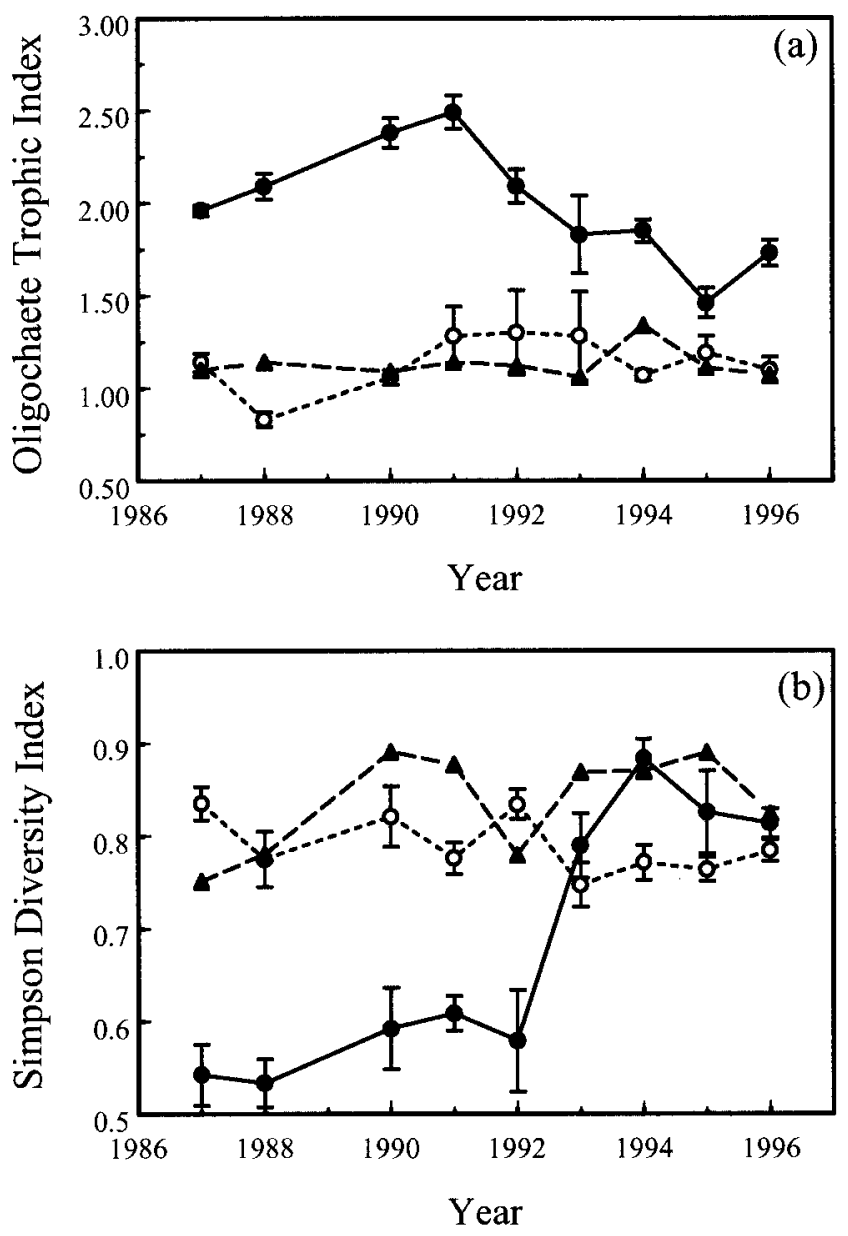

FIG. 3. Mean ( \pm SE) value of the oligocheate trophic index (a) and Simpson's Diversity Index $(b)$ in silt $(\bullet)$, silty sand $(\Delta)$, and sand $(\mathrm{O})$ in the inner bay, 1987 to 1996. The indices were calculated from all sampling dates at a particular site, and the mean and standard error were determined for all sites within a particular substrate.

of all oligochaetes in the pre- and post-Dreissena periods, respectively, at sites in the deepwater/silt region, and the oligochaete trophic index indicated a distinct shift from eutrophic to mesotrophic species after Dreissena colonization (Fig. 3a). The mean index value declined from $2.14 \pm 0.12$ to 1.72 \pm 0.09 ( $\mathrm{P}<0.05)$. The proportion of the following species indicative of considerable enrichment decreased: L. hoffmeisteri (33.4\% to $22.2 \%$ ), L. cervix (25.8\% to $8.7 \%)$, and Tubifex tubifex $(4.6 \%$ to $0.2 \%$ ), while the following species indicative of only slight enrichment increased: Aulodrilus limnobius $(0.0 \%$ to $10.3 \%)$, and Aulodrilus pigueti (1.3\% to $12.5 \%)$. 
Densities of chironomids declined in the first few years after the peak in Dreissena at sites in the deep water/silt region, but then increased so that the difference in the pre- and post-Dreissena periods was not significant $(\mathrm{P}>0.05)$ (Table 5). By 1995 and 1996, chironomid densities were similar to or greater than densities found in the pre-Dreissena period. While the total number of species collected in the two periods was similar (16 and 14), there were shifts in proportions of the dominant taxa. The proportion of the following species increased the most: C. anthracinus (25.4\% to $34.7 \%)$, Chironomus sp. (2.0\% to $17.5 \%)$, Cryptochironomus digitatus $(0.3 \%$ to $9.5 \%)$, and Procladius sp. (3.3\% to $7.7 \%$ ), and the following species declined: $\mathrm{Chi}$ ronomus semireductus gr. (52.6\% to $25.8 \%$ ), and Chironomus plumosus (12.5\% to $0.0 \%)$. The latter two species are indicative of highly eutrophic conditions (Saether 1979), and their decline would indicate an improved trophic state, as indicated by the oligochaete trophic index. At these sites, the Simpson Diversity Index increased significantly $(\mathrm{P}<$ 0.05) after Dreissena colonization, likely as a result of the decline in overall abundance of oligochaetes and the increase in mesotrophic-indicator species (Fig. 3b).

In the outer bay, significant differences in densities between the pre- and post-Dreissena periods were not detected for any of the major taxonomic groups at the three sites sampled $(\mathrm{P}>0.05)$. However, after Dreissena became established, there was a downward trend in densities of sphaeriids at the 13-m site and Diporeia at the 28-m site (Table 5). The downward trend was not apparent until after 1993; if this year was not considered as part of the post-Dreissena period, the decline was significant $(\mathrm{P}<0.05)$ for both taxa. Oligotrophic forms dominated the oligochaete community in the outer bay throughout the sampling period. On an annual basis, the oligochaete trophic index at the three sites varied from 0.55 to 1.43 , and Simpson's Diversity Index varied from .69 to .90 . Differences between the pre- and post-Dreissena periods were not significant for either index $(\mathrm{P}>0.05)$.

Minor taxa collected in the bay during the study period included Gastropoda (Amnicola limosa, Probythinella lacustris, Bythinia tentaculata, Physa sp., Pleurocera acuta, Valvata sincera, and Valvata tricarinata), Ephemeroptera (Caenis sp., Hexagenia sp.), Trichoptera (Oecetis sp.), and Isopoda (Caecidotea racovitzai). Differences were noted in two of these taxa relative to Dreissena colonization. Oecetis $\mathrm{sp}$. was more abundant in the post-Dreissena

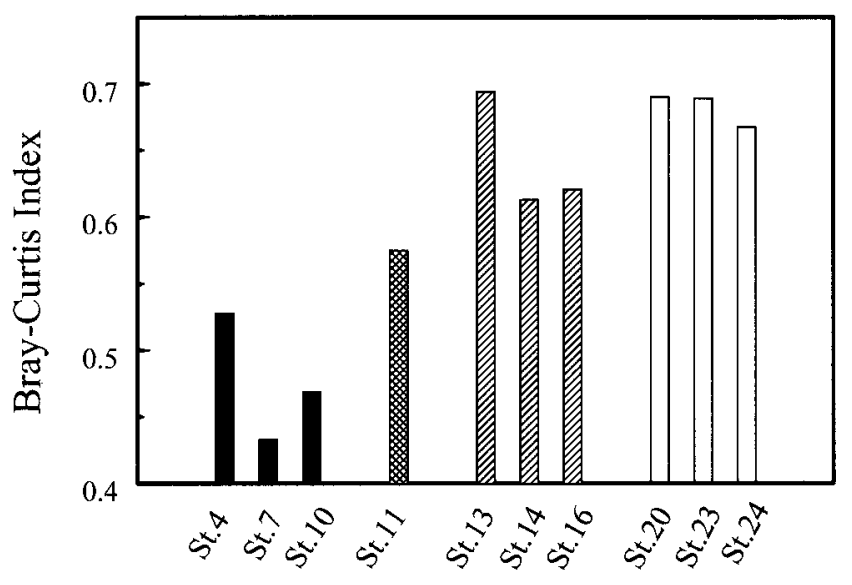

Station

FIG. 4. Values of the Bray-Curtis Index at the ten sites sampled over the entire 1987 to 1996 period. The index shows the degree of similarity between communities (excluding Dreissena) in the pre- and post-Dreissena periods (1987 to 1990 vs 1993 to 1996) at each site. solid dark: sites in deep water/silt region in inner bay, cross-hatched: site in mid-depth/silty sand region in inner bay; diagonal: sites in shallow water/sand region in inner bay; solid white: sites in outer bay.

period at the silty sand site in the inner bay $\left(0 / \mathrm{m}^{2}\right.$ to $10 / \mathrm{m}^{2}$ ), while $C$. racovitzai was less abundant at the 28 - $\mathrm{m}$ site in the outer bay $\left(117 / \mathrm{m}^{2}\right.$ to $\left.1 / \mathrm{m}^{2}\right)$.

In comparing communities in the pre- and postDreissena periods at each of the ten sites, the Bray Curtis Index indicated that communities at sites in the deepwater/silt region changed the most (were least similar), while communities at the outer bay sites changed the least (were most similar) (Fig 4). The index ranged from 0.43 to 0.53 at the former sites and from 0.67 to 0.69 at the latter sites.

\section{Biomass Trends and Comparisons, Pre- and Post-Dreissena}

As found for density, changes in total macroinvertebrate biomass (excluding Dreissena) varied by substrate and depth. Biomass at sites with sand substrates in the inner bay was significantly greater $(\mathrm{P}<0.05)$ in the post-Dreissena period (1993 to 1996) compared to the pre-Dreissena period (1987 to 1990), but differences were not significant at sites with silty sand or silt substrates $(\mathrm{P}>0.05)$. Biomass at sites with sand increased from a mean of 0.10 to $0.43 \mathrm{~g} / \mathrm{m}^{2}$ (Fig. 5). This increase was 


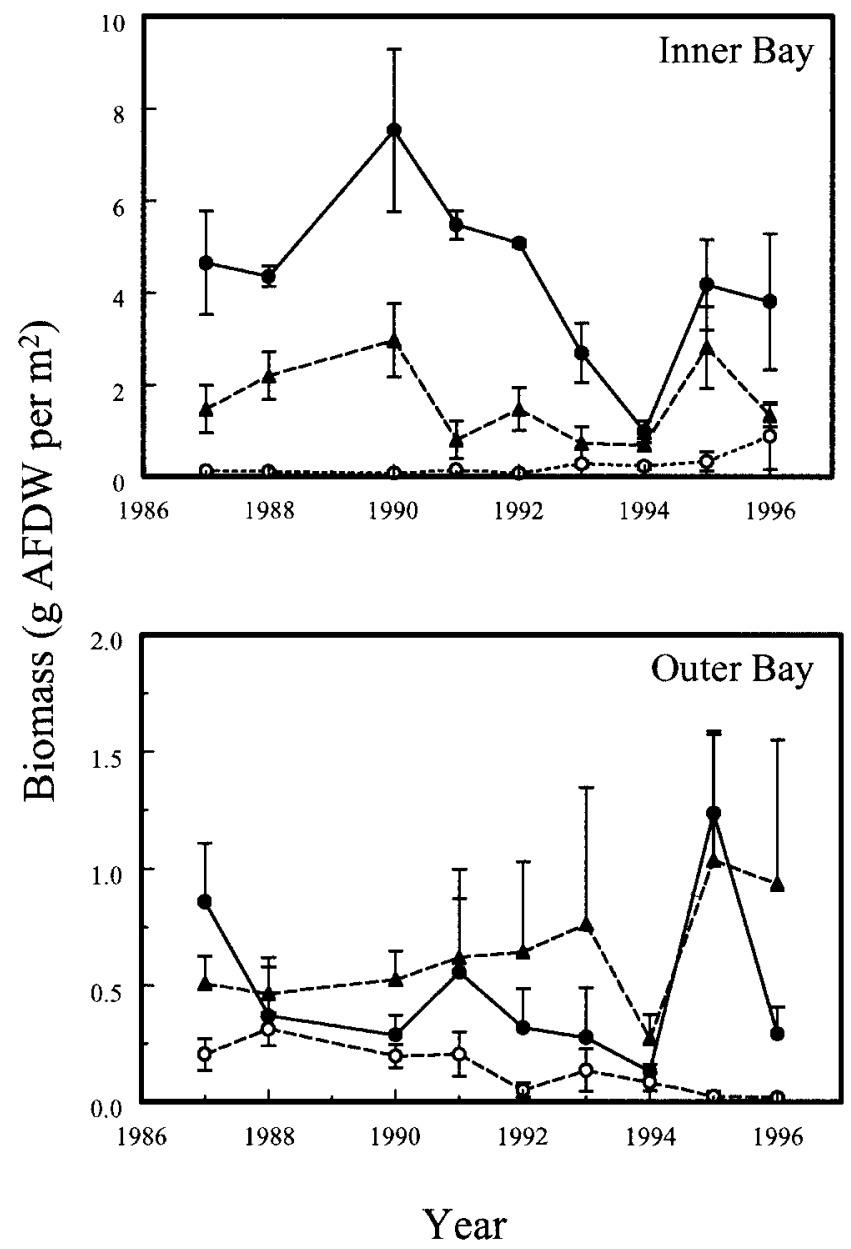

FIG. 5. Mean biomass (g AFDW/m $m^{2} \pm S E$ ) of benthic macroinvertebrates (excluding Dreissena) in the inner bay (upper) and outer bay (lower), 1987-96. inner bay: $\bullet=$ deep water/silt sites, $\Delta=$ silty sand, $\mathrm{O}=$ sand; outer bay: $\bullet=$ St. $24(13 \mathrm{~m})$, $\Delta=S t .20(16 m), \mathrm{O}=S t .23(28 \mathrm{~m})$.

mostly a result of greater numbers of Gammarus, although a few large gastropods (Bythinia tentaculata and Pleurocera acuta) were found in 1996 and not in other years. Gammarus accounted for $30 \%$ and $56 \%$ of total biomass in the pre- and post-periods, respectively. Although not significant, mean biomass at sites in the deep water/silt region decreased from 5.5 to $2.9 \mathrm{~g} / \mathrm{m}^{2}$, mostly because of lower densities of oligochaetes in the post-Dreissena period. Chironomids dominated the biomass at sites in the deepwater/silt region, accounting for $69 \%$ of total biomass in the pre-Dreissena period and $89 \%$ in the post-Dreissena period.

In the outer bay, significant differences in total biomass between the pre- and post-Dreissena periods were not detected at the two shallow sites (Stations 24 and 20). Large year-to-year variation occurred at both sites during the post-Dreissena period (Fig. 5). Biomass at the deeper 28-m site (Station 23) was significantly lower in the post-Dreissena period $(\mathrm{P}<0.05)$, and this decline can be attributed mainly to decreased numbers of the amphipod Diporeia (Table 5).

\section{DISCUSSION}

Trends in densities of the major macroinvertebrate groups from 1987 to 1996 in Saginaw Bay can be put into a historical perspective by examining densities reported in studies over several decades beginning in the mid-1950s (Surber 1954, 1955; Alexander 1963; Shannon et al. 1967; Schneider et al. 1969; Batchelder 1973; Michigan Department of Natural Resources [MDNR] unpublished data). Densities from previous studies were converted to Ponar equivalents as given in Nalepa et al. (2002). An examination of historical trends was limited to the deepwater/silt region since organic materials from both allochthonous and autochthonous sources eventually focus and settle in this region (Robbins 1981), and therefore changes in the macroinvertebrate community most closely reflect shifts in the overall productivity of the system.

In the deepwater/silt region, both oligochaetes and chironomids increased between the 1950s and the 1960s/early 1970s (Fig. 6). These increases were likely a result of increasing nutrient loads and high system productivity (Vollenweider et al. 1974). This was also the time period over which the burrowing mayfly Hexagenia, a pollution sensitive form, disappeared from the bay (Schneider et al. 1969). Phosphorus abatement programs were initiated in the mid-1970s, and total phosphorus loads in the inner bay declined 55\% between 1974 and 1980 (Bierman et al. 1984). This resulted in a 53 to $61 \%$ decline in chlorophyll (20.6 to $12.2 \mu \mathrm{g} / \mathrm{L}$ in spring and 29.1 to $12.2 \mu \mathrm{g} / \mathrm{L}$ in fall) (Bierman et al. 1984), a reduction in populations of eutrophic indicator species of phytoplankton (Stoermer and Theriot 1985), and the elimination of nuisance blooms of blue-green algae (Stoermer et al. 1983). Further reductions in total phosphorus and chlorophyll were not apparent between 1980 and 1991 (Fahnenstiel et al. 1995a).

Despite improvements in water quality, densities of the dominant macroinvertebrate groups, oligochaetes and chironomids, changed little or in- 


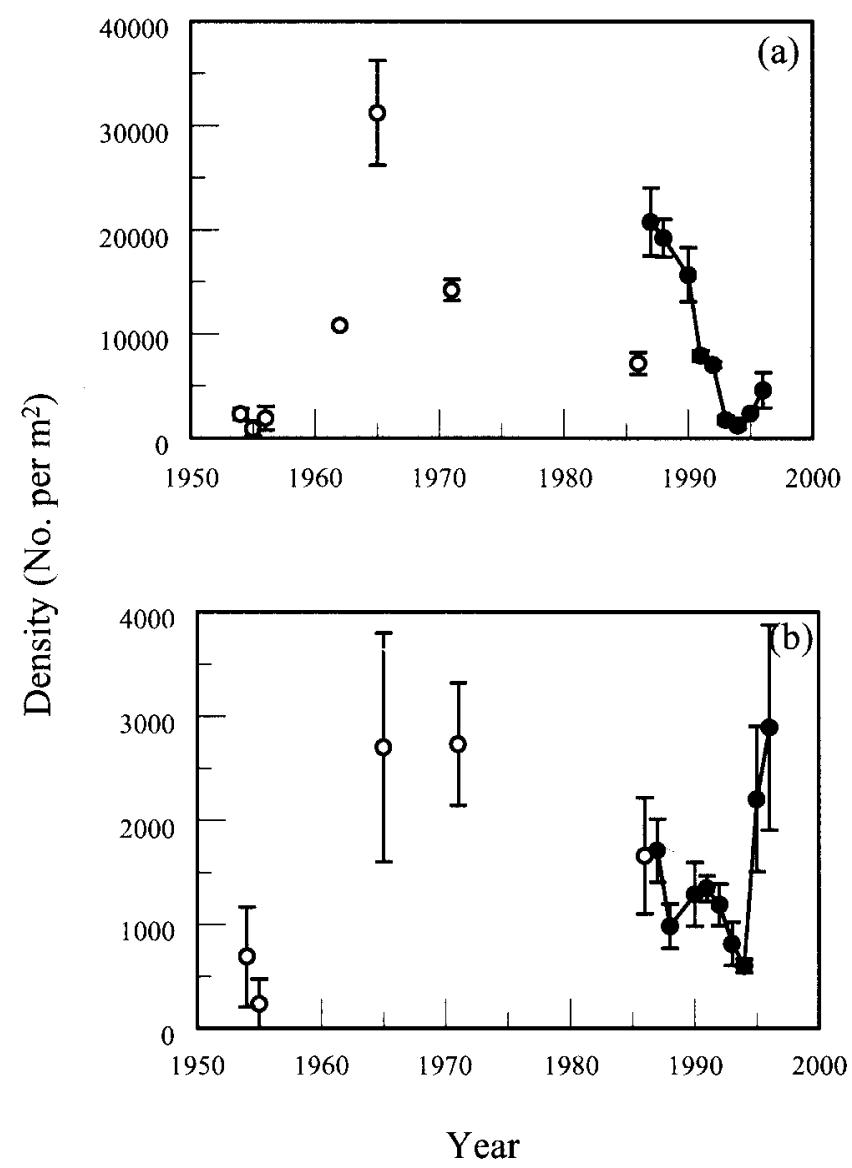

FIG. 6. Comparison of mean densities (no. $/ \mathrm{m}^{2} \pm$ $S E$ ) of oligochaetes (a) and chironomids (b) found in this study $(\bullet)$ to densities reported in previous studies $(\mathrm{O})$ at sites in the deepwater/silt region of the inner Saginaw Bay. Densities were taken from the following studies: 1954 (Surber 1954), 1955 (Surber 1955), 1962 (Alexander 1963), 1965 (Shannon et al. 1967), 1971 (Batchelder 1973), and 1986 (MDNR unpublished data).

creased between 1971 and 1987 to 1990 . This finding is surprising, particularly for oligochaetes, given that other studies in the Great Lakes have found decreases in abundances after abatement programs (Johnson and McNeil 1986, Schloesser et al. 1995, Nalepa et al. 1998). A close examination of trends suggests that densities of at least oligochaetes were abnormally high in 1987 to 1990 and likely not representative of the post abatement period. For instance, a 1986 survey reported a mean oligochaete density of $7,200 / \mathrm{m}^{2}$ in the deepwater/silt region (MDNR unpublished data) (Fig. 6). This value was far less than the mean of
$20,800 \mathrm{~m}^{2}$ in 1987 , just 1 year later. By 1991, densities declined back to $7,900 / \mathrm{m}^{2}$. Given the magnitude of this increase and decrease over such a short time period, it is possible that densities were affected by a short-term storm event that occurred in fall 1986. A 100-year flood displaced 8 to $200 \mathrm{~cm}$ of surface sediment material from river margins into the bay (Ludwig et al. 1993). These organic inputs would have been deposited in the deepwater/silt region and perhaps led to the dramatic increase in oligochaete densities the following year. Densities of tubificid oligochaetes can increase rapidly after periods of high organic sedimentation (nearly a 2-fold increase in just a few months; Lang and Hutter 1981). Consistent with this theory, the highest proportion of immature tubificids over the entire sampling period occurred in 1987 (93\%). Subsequent declines, particularly after 1990 but before Dreissena, may have been a result of the population returning to levels more at equilibrium with the carrying capacity of the bay prior to this discharge event. Mean annual water temperatures in the inner bay in 1987 and 1988 were higher than in the previous 6 years (McCormick and Fahnenstiel 1999) and this may have also contributed to greater oligochaete recruitment. If densities in 1986 and 1991 are considered to be typical of the post-abatement period, then oligochaete densities declined about $45 \%$ from pre-abatement densities found in 1971, and chironomids declined by $40 \%$. However, despite these apparent declines in densities, eutrophic-indicator species of both groups still dominated the community.

Several distinct changes occurred in the macroinvertebrate community just after the peak of Dreissena in 1992. At sites in the deepwater/silt region, density and biomass of both oligochaetes and chironomids decreased sharply, even though few mussels were ever found in this region. It is likely that, at least initially, filtering activities of abundant Dreissena populations in the sand/shallow water regions of the bay led to diminished organic inputs into the deepwater/silt region, leading to a decline in densities of these two groups. Strayer and Smith (2001) reported a similar pattern in the Hudson River estuary; that is, Dreissena populations in shallow-water areas had a negative impact on macroinvertebrate populations in adjacent deepwater areas where no Dreissena were present. In inner Saginaw Bay, this response was evident for just a few years after the 1992 peak in Dreissena. By 1995 to 1996, oligochaete densities had in- 
creased from earlier lows, and chironmid densities were greater than found prior to Dreissena. The oligochaete trophic index declined after 1992 and remained lower through 1996, indicating that increased densities in 1995 and 1996 consisted of species reflective of more oligotrophic conditions.

In terms of other taxa, of particular interest was the number of Hexagenia spp. collected in the deepwater/silt region of the inner bay. As noted, this pollution-sensitive species was once abundant in this habitat, but disappeared in the 1950s. Over the 9-year study period, five individuals were collected in the inner bay, two in 1990 and three in 1994, and all were found at Station 11 (Nalepa et al. 2002). In western Lake Erie, Hexagenia returned to former abundances in the early 1990s after a decades-long absence (Edsall et al. 1999). Hexagenia was not found in Saginaw Bay in the early 1970s (Batchelder 1973; GLRD unpublished), so the finding of a few individuals is noteworthy. Yet a large-scale return to Saginaw Bay, although predicted (Schaeffer et al. 2000), had yet to occur through 1996.

There were two clear responses to the establishment of Dreissena in the shallow water/sand region: an increase in Gammarus and a decrease in Sphaeriidae. Similar to the present study, most other studies have reported a similar response in these two taxa (Howell et al. 1996, Haynes et al. 1999). Gammarus apparently benefits from increased habitat complexity created by Dreissena clusters, and from increased food availability generated by mussel biodeposits (Ricciardi et al. 1997, Stewart et al. 1998). In this study, densities of Gammarus in the post-Dreissena period (240 to $494 / \mathrm{m}^{2}$ ) exceeded historical densities $\left(152 / \mathrm{m}^{2}\right.$ in 1956 [J. C. Schneider unpublished data] and $97 / \mathrm{m}^{2}$ in 1971 [Batchelder 1973]). The decline in sphaeriids has been attributed to physical attachment by Dreissena, or to competition for food (Lauer and McComish 2001, Strayer and Smith 2001).

In contrast to some studies, we did not observe any changes in densities of oligochaetes or chironomids in response to Dreissena in the shallow water/sand region. Relative impacts of Dreissena on these two groups are variable and appear to be a function of where samples were collected relative to Dreissena clusters. Some studies have shown that densities of these two groups are higher within, or adjacent to, mussel clusters than in surrounding substrates (Karatayev et al. 1997, Bially and MacIsaac 2000). Yet other studies have shown that, overall, densities of oligochaetes and chironomids did not change or declined after Dreissena introduction (Johannsson et al. 2000, Kilgour et al. 2000, Strayer and Smith 2001). Mussels do provide more suitable habitat and/or food for these groups but, as argued by Strayer and Smith (2001), local studies within mussel beds neglect changes on a broader spatial scale. The local impact of Dreissena on oligochaetes and chironomids is a function of mussel density (Karatayev et al. 1997). At sand sites in the inner bay, mussel densities in individual replicates with mussels ranged from 1 to $42,390 / \mathrm{m}^{2}$ (mean = $3,855 / \mathrm{m}^{2}$ ). Yet even with these densities on a local scale, no relationship between Dreissena and densities of oligochaetes and chironomids was observed.

The decline of the amphipod Diporeia in the outer bay is consistent with declines in other regions of the Great Lakes after Dreissena became established (Dermott and Kerec 1997, Nalepa et al. 1998, Lozano et al. 2001). A common theory for the decline in Diporeia is that mussels are outcompeting Diporeia for food resources settling to the bottom, particularly diatoms (Nalepa et al. 1998, Dermott 2001). Inconsistent with this theory, at least in the outer bay, is the fact that neither chlorophyll nor diatom biovolumes in the water column declined at Station 23 between 1991 and 1996 (Johengen et al. 2000; H. A. Vanderploeg unpublished data). Diporeia densities declined at Station 23 just 2 years after Dreissena peaked at shallower sites within the outer bay (Stations 19 and 27), yet Dreissena was never collected at Station 23 over the entire sampling period. While Diporeia has declined in areas where both Diporeia and Dreissena are found in immediate proximity (Dermott and Kerec 1997), the decline at Station 23 in outer Saginaw Bay provides another example of populations that have declined in areas removed from Dreissena, and where food resources are still apparently available to sustain at least some of the population (Dermott 2001).

Based on the relative proportion of the various substrate types within the inner bay (57\% sand, $16 \%$ silty sand, and $27 \%$ silt; Robbins 1981), and mean biomass of benthic communities within each substrate type, system-wide changes in benthic biomass were calculated for each sampling year. The inner bay is a well-mixed, semi-confined system, and thus net gains or losses of benthic biomass may be interpreted relative to overall system productivity. When considered as a whole, biomass of the non-dressenid macroinvertebrate community was affected by Dreissena for only a short time period (Table 6). While decreases were apparent immediately after the peak in Dreissena in 1992, biomass 
increased after Dreissena populations apparently stabilized. Mean yearly biomass of 2.30 and $2.72 \times$ $10^{9} \mathrm{~g}$ in 1995 and 1996 were not different from values of 2.14 to $3.57 \times 10^{9}$ in 1987 to 1990 prior to Dreissena. Thus, the energetic demands of Dreissena ultimately did not come at the expense of the non-dreissenid benthic community. The same finding was reported for the western basin of Lake Erie (Johannsson et al. 2000), a system similar to inner Saginaw Bay. When Dreissena is included, standing stocks of the total benthic community in the inner bay were 2 to 6 times greater in 1993 to $1996 \mathrm{com}$ pared to 1987 to 1990 (Table 6). The question remains how the non-dreissenid benthic community can be sustained given the added energetic requirements of the dreissenid population. The system is dominated by detritivores (oligochaetes and chironomids), and conceivably the availability of detrital food did not decline or perhaps even increased. While chlorophyll levels declined $61 \%$ in the inner bay after Dreissena became established (Fahnenstiel et al. 1995a), standing stocks of benthic macroalgae and submersed macrophytes increased because of increased light penetration to the bottom (Skubinna et al. 1995, Lowe and Pillsbury 1995). As calculated by Fahnenstiel et al. (1995b), a decrease in phytoplankton production was almost compensated for by an increase in benthic algal production, without even considering a potential increase in other benthic producers such as vascular hydrophytes and metaphytonic algae. Moreover, the potential for increased nutrient supply rates resulting from Dreissena excretion would enhance growth rates of both benthic and pelagic algae (Heath et al. 1995). In addition, large, late summer/fall blooms of the cyanophyte Microcystis have been documented in the inner bay beginning in 1994 as a result of selective rejection by Dreissena (Vanderploeg et al. 2001). When settled to the bottom, this alga may enhance food availability to the benthos, either directly or indirectly through increased bacterial production (Brunberg and Bostrom 1992).

A number of studies have examined macroinvertebrate changes within a specific habitat type, such as within hard-substrate habitats colonized by Dreissena, but few have determined changes on a system-wide basis. After Dreissena colonized the Hudson River, Strayer and Smith (2001) reported a $10 \%$ gain in non-dreissenid biomass at shallow water sites, but a $50 \%$ loss at deepwater sites. Based on the proportion that each habitat comprised of the river system, it was estimated that non-
TABLE 6. Biomass $\left(\mathrm{g} A F D W \times 10^{9}\right)$ of benthic macroinvertebrates and Dreissena polymorpha in inner Saginaw Bay from 1987 to 1996. Values determined by multiplying mean biomass in each substrate type by the proportion each substrate comprised of the inner bay bottom.

\begin{tabular}{cccr}
\hline \hline Year & $\begin{array}{c}\text { Benthic } \\
\text { Macroinvertebrates }\end{array}$ & Dreissena & Total \\
\hline 1987 & 2.29 & 0.00 & 2.29 \\
1988 & 2.14 & 0.00 & 2.14 \\
1990 & 3.57 & 0.00 & 3.57 \\
1991 & 2.70 & 9.57 & 12.27 \\
1992 & 2.43 & 60.44 & 62.87 \\
1993 & 1.55 & 4.39 & 5.82 \\
1994 & 0.70 & 3.02 & 3.72 \\
1995 & 2.30 & 4.01 & 6.31 \\
1996 & 2.72 & 13.08 & 15.80 \\
\hline
\end{tabular}

dreissenid biomass declined $40 \%$ on a riverwide basis. In comparison, a $58 \%$ overall decline was found in non-dreissenid biomass in the inner bay within 2 years after the peak in Dreissena (1993 and 1994), but then biomass increased such that there was no difference in biomass 3 to 4 years (1995 and 1996) after the Dreissena peak when compared to the pre-Dreissena period (1987 to 1990). In 1995 and 1996, mean biomass at the shallow-water/sand sites increased by $84 \%$ compared to 1987 to 1990 , while biomass at the deepwater/silt sites declined by $27 \%$.

Even though total non-dreissenid macroinvertebrate biomass did not change as a result of the introduction of Dreissena in the inner bay, Dreissena likely enhanced the amount of food available to upper trophic levels. When considering macrobenthic forms that are most readily fed upon by many fish such as chironomids, Gammarus, and sphaeriids (Wells 1980), the decline in sphaeriids was more than offset by the increase in Gammarus, and no long-term changes were observed in biomass of chironomids. For example, yellow perch in the inner bay fed primarily on chironomids in the late 1980s (Schaeffer et al. 2000), but also will feed on amphipods when available (Haygood and Margraf 1987). The 5-fold increase in Gammarus over most of the inner bay without a corresponding decline in chironomids will likely have a positive effect on this fish species. The assumption, of course, is that Gammarus is available to fish and not sheltered from predation within mussel clusters. When con- 
sidered as a whole, the fish community in the inner bay shifted to more benthic-feeding forms since Dreissena became established (Thomas and Haas 1997). In the outer bay, the introduction of Dreissena will probably have a more negative impact on upper trophic levels. Although macroinverteberate biomass at shallower water sites in the outer bay were not affected by Dreissena, the decline in biomass at deep-water sites as a result of the loss of Diporeia will likely adversely affect some fish species (Pothoven et al. 2001).

In summary, it was difficult to determine a clear response of the benthic macroinvertebrate community to phosphorus abatement efforts over the time period of this study. The community in the deepwater/silt region of the inner bay, the best location in the bay to interpret long-term trends, was likely affected by a major storm event that occurred just prior to our initial sampling. This confounded interpretations of abatement efforts. Densities of the two major groups, oligochaetes and chironomids, were likely $45 \%$ and $40 \%$ lower after abatement and before Dreissena colonization, but eutrophic species still dominated each of these groups. After Dreissena became established, oligochaete densities initially declined in the deepwater/silt region of the inner bay, but then returned to values near those found in the pre-Dreissena period. Also, the oligochaete community shifted to species more indicative of an improved trophic state, and overall species diversity increased. Sphaeriids declined in the shallow/sand and silty sand regions, but Gammarus increased. Species diversity in these regions was little changed after Dreissena colonization. Despite shifts in community composition, non-dreissenid biomass in the entire inner bay was unchanged relative to biomass found in the preDreissena period by the end of the sampling period. In the outer bay, the most significant change was a decrease in biomass at deeper depths as a result of a decline in Diporeia. The increase of Gammarus in the shallow, nondepositional regions of the inner bay, and the loss of Diporeia in the deeper regions of the outer bay have contrasting implications to the food web.

\section{ACKNOWLEDGMENTS}

We thank B. Burns for his help and cooperation during field operations; M. Ford, W. Gordon, G. Gostenik, and D. Hartson for picking and sorting the organisms; M. Winnell and S. Mozley for providing unpublished 1972 data; R. Haas, P. Hudson, and S. Adlerstien for providing unpublished 1986 data; and D. Schloesser, T. Reynoldson, and two anonymous reviewers for helpful suggestions that improved the manuscript. This is GLERL Contribution No. 1246.

\section{REFERENCES}

Alexander, H.C. 1963. Bottom Fauna Survey, Saginaw Bay, June 15-16, 1962. Internal Report, Dow Chemical Company, Midland, MI.

Bially, A., and MacIsaac, H.J. 2000. Fouling mussels (Dreissena spp.) colonize soft sediments in Lake Erie and facilitate benthic invertebrates. Freshwater Biology 43:85-97.

Batchelder, T.L. 1973. Saginaw Bay Ecological Survey, 1971. Internal Report, Dow Chemical Company, Midland, MI.

Beeton, A.M., Smith, S.H., and Hooper, F.H. 1967. Physical Limnology of Saginaw Bay, Lake Huron. Great Lakes Fishery Commission Technical Report 12.

Bierman, V.J., Dolan, D.M., and Kasprzyk, R. 1984. Retrospective analysis of the response of Saginaw Bay, Lake Huron, to reductions in phosphorus loadings. Environ. Sci. Technol. 18:23-31.

Botts, P.S., Patterson, B.A., and Schloesser, D.W. 1996. Zebra mussel effects on benthic invertebrates: physical or biotic? J. N. Am. Benthol. Soc. 15:179-184.

Bray, J.R., and Curtis, J.T. 1957. An ordination of the upland forest communities of southern Wisconsin. Ecol. Monogr. 27:325-349.

Brunberg, A.K., and Bostrom, B. 1992. Coupling between benthic biomass of Microcystis and phosphorus release from sediments of a highly eutrophic lake. Hydrobiologia 235/236:375-385.

Cook, D.G., and Johnson, M.G. 1974. Benthic macroinvertebrates of the St. Lawrence Great Lakes. J. Fish. Res. Board Can. 31:763-782.

Danek, L.J., and Saylor, J.H. 1977. Measurements of the summer currents in Saginaw Bay, Michigan. J. Great Lakes Res. 3:65-71.

Dermott, R. 2001. Sudden disappearance of the amphipod Diporeia from Lake Ontario, 1993-95. J. Great Lakes Res. 27:423-433.

and Kerec, D. 1997. Changes in the deepwater benthos of eastern Lake Erie since the invasion of Dreissena: 1979-1993. Can. J. Fish. Aquat. Sci. 54: 922-930.

Edsall, T.A., Madenjian, C.P., and Manny, B.A. 1999. Burrowing mayflies in Lake Erie-a review. In State of Lake Erie (SOLE)-Past, Present, and Future, pp. 219-231, M. Munawar, T. Edsall, and I. F. Munawar (eds.). Backhuys Publishers, The Netherlands.

Erman, D.C., and Erman, N.A. 1975. Macroinvertebrate composition and production on some Sierra Nevada minerotrophic peatlands. Ecology 56:591-603. 
Fahnenstiel, G.L., Lang, G.A., Nalepa , T.F., and Johengen, T.H. 1995a. Effects of zebra mussel (Dreissena polymorpha) colonization on water quality parameters in Saginaw Bay, Lake Huron. J. Great Lakes Res. 21: 435-448.

Bridgeman, T.B., Lang, G.A., McCormick, M.J., and Nalepa, T.F. 1995b. Phytoplankton productivity in Saginaw Bay, Lake Huron: effects of zebra mussel (Dreissena polymorpha) colonization. J. Great Lakes Res. 21:465-475.

Haygood, R.S., and Margraf, F.J. 1987. Eutrophication effects on prey size and food availability to yellow perch in Lake Erie. Trans. Amer. Fish. Soc. 116:210-223.

Haynes, J.M., Stewart, T.W., and Cook, G.E. 1999. Benthic macroinvertebrate communities in southwestern Lake Ontario following invasion of Dreissena: continuing change. J. Great Lakes Res. 25:828-838.

Heath, R.T., Fahnenstiel, G.L., Gardner, W.S., Cavaletto, J.F., and Hwang, S.J. 1995. Ecosystem-level effects of zebra mussels (Dreissena polymorpha): an enclosure experiment in Saginaw Bay, Lake Huron. J. Great Lakes Res. 21:501-516.

Howell, E.T., Marvin, C.H., Bilyea, R.W., Kauss, P.B., and Somers, K. 1996. Changes in environmental conditions during Dreissena colonization of a monitoring station in eastern Lake Erie. J. Great Lakes Res. 22: 744-756.

Howmiller, R.P., and Scott, M.A. 1977. An environmental index based on relative abundance of oligochaete species. J. Water Pollut. Control Fed. 49:809-815.

Hruby, T. 1987. Using similarity measures in benthic impact assessments. Envir. Monit. Assess. 8:163-180.

Johannsson, O.E., Dermott, R., Graham, D.M., Dahl, J.A., Millard, E.S., Myles, D.D., and LeBlanc, J. 2000. Benthic and pelagic secondary production in Lake Erie after the invasion of Dreissena spp. with implications for fish production. J. Great Lakes Res. 26:31-54.

Johengen, T.H., Nalepa, T.F., Lang, G.A., Fanslow, D.L., Vanderploeg, H.A., and Agy, M.A. 2000. Physical and chemical variables of Saginaw Bay, Lake Huron in 1994-96. NOAA Technical Memorandum GLERL-115, Great Lakes Environmental Research Laboratory, Ann Arbor, MI.

Johnson, M.G., and Brinkhurst, R.O. 1971. Production of benthic invertebrates of Bay of Quinte and Lake Ontario. J. Fish. Res. Board Can. 28:1699-1714. and McNeil, O.C. 1986. Changes in abundance and species composition in benthic macroinvertebrate communities of the Bay of Quinte, 1966-1984. In Project Quinte: point-source phosphorus control and ecosystem response in the Bay of Quinte, Lake Ontario, C.K. Minns, D.A. Hurley, and K.H. Nicholls (eds.), pp. 177-189. Can. Spec. Publ. Fish. Aquat. Sci. 86.

Karatayev, A.Y., Burlakova, L.E., and Padilla, D.K.
1997. The effects of Dreissena polymorpha (Pallas) invasion on aquatic communities in eastern Europe. $J$. Shellfish Res. 16:187-203.

Kilgour, B.W., Bailey, R.C., and Howell, E.T. 2000. Factors influencing changes in the nearshore benthic community on the Canadian side of Lake Ontario. $J$. Great Lakes Res. 26:272-286.

Kreiger, K.A., and Ross, L.S. 1993. Changes in the benthic macroinvertebrate community of the Cleveland Harbor area of Lake Erie from 1978 to 1989. J. Great Lakes Res. 237-249.

Lang, C., and Hutter, P. 1981. Structure, diversity, and stability of two oligochaete communities according to sedimentary imputs in Lake Geneva (Switzerland). Schweiz. Z. Hydrol. 43:265-276.

Lauer, T.E., and McComish, T.S. 2001. Impact of zebra mussels (Dreissena polymorpha) on fingernail clams (Sphaeriidae) in extreme southern Lake Michigan. $J$. Great Lakes Res. 27:230-238.

Lauritsen, D.D., Mozley, S.C., and White, D.S. 1985. Distribution of oligochaetes in Lake Michigan and comments on their use as indices of pollution. $J$. Great Lakes Res. 11:67-76.

Lowe, R.L., and Pillsbury, R.W. 1995. Shifts in benthic algal community structure and function following the appearance of zebra mussel (Dreissena polymorpha) in Saginaw Bay, Lake Huron. J. Great Lakes Res. 21:558-566.

Lozano, S.J., Scharold, J.V., and Nalepa, T.F. 2001. Recent declines in benthic macroinvertebrate densities in Lake Ontario. Can. J. Fish. Aquat. Sci. 58:518-529.

Ludwig, J.P., Auman, H.J., Kurita, H., Ludwig, M.E., Campbell, L.M., Giesy, J.P., Tillit, D.E., Jones, P., Yamashita, N., Tanabe, S., and Tatsukawa, R. 1993. Caspian tern reproduction in the Saginaw Bay ecosystem following a 100-year flood event. J. Great Lakes Res. 19:96-108.

McCormick, M.J., and Fahnenstiel, G.L. 1999. Recent climatic trends in nearshore water temperatures in the St. Lawrence Great Lakes. Limnol. Oceanogr. 44:530-540.

Milbrink, G. 1983. An improved environmental index based on the relative abundance of oligochaete species. Hydrobiologia 102:89-97.

Mozley, S.C., and Howmiller, R.P. 1977. Environmental status of the Lake Michigan region: zoobenthos of Lake Michigan. Argonne National Lab. Rep. No. ANL/ES-40. Vol. 6. U. S. Energy Research and Development Administration.

Nalepa, T.F., and Fahnenstiel, G.L. 1995. Dreissena polymorpha in the Saginaw Bay, Lake Huron ecosystem: overview and perspective. J. Great Lakes Res. 21:411-416.

Quigley, M.A., Childs, K.M., Gauvin, J.M., Heatlie, T.S., Parker, M.P., and Vanover, L. 1985. Macrobenthos of southern Lake Michigan, 1980-81. 
NOAA Data Rep. ERL-GLERL-28. Great Lakes Environmental Research Laboratory, Ann Arbor, MI. Caveletto, J.F., Ford, M., Gordon, W.M., and Wimmer, M. 1993. Seasonal and annual variation in weight and biochemical content of the zebra mussel Dreissena polymorpha. J. Great Lakes Res. 19: 541-552.

, Wojcik, J.A., Fanslow, D.L., and Lang, G.A. 1995. Initial colonization of the zebra mussel (Dreissena polymorpha) in Saginaw Bay, Lake Huron: population recruitment, density and size structure. $J$. Great Lakes Res. 21:417-434.

Fahnenstiel, G.L., McCormick, M.J, Johengen, T.H., Lang, G.A., Cavaletto, J.F., and Goudy, G. 1996. Physical and chemical variables of Saginaw Bay, Lake Huron in 1991-93. NOAA Technical Memorandum GLERL-91, Great Lakes Environmental Research Laboratory, Ann Arbor, MI.

Hartson, D.J., Fanslow, D.L., Lang, G.A., and Lozano, S.J. 1998. Declines in benthic macroinvertebrate populations in southern Lake Michigan, 1980-93. Can. J. Fish. Aquat. Sci. 55:2402-2413.

, Fanslow, D.L., Lansing, M.B., Lang, G.L., Ford, M., Gostenik, G., and Hartson, D.J. 2002. Abundance, biomass, and species composition of benthic macroinvertebrate populations in Saginaw Bay, Lake Huron. NOAA Technical Memorandum GLERL-122, Great Lakes Environmental Research Laboratory, Ann Arbor, MI.

Pontasch, K.W., and Brusven, M.A. 1988. Diversity and community comparison indices: assessing macroinvertebrate recovery following a gasoline spill. Wat. Res. 22:619-626.

, Smith, E.P., and Cairns, J., Jr. 1989. Diversity indices, community comparison indices and canonical discriminant analysis: interpreting the results of multispecies toxicity tests. Wat. Res. 23:1229-1238.

Pothoven, S.A., Nalepa, T.F., Schneeberger, P.J., and Brandt, S.B. 2001. Changes in diet and body condition of lake whitefish in southern Lake Michigan associated with changes in benthos. North Amer. J. Fish. Manag. 21:876-883.

Quigley, M.A., and Lang, G.A. 1989. Measurement of amphipod body length using a digitizer. Hydrobiologia 171:255-258.

Ricciardi, A., Whoriskey, F.G., and Rasmussen, J.B. 1997. The role of the zebra mussel (Dreissena polymorpha) in structuring macroinvertebrate communities on hard substrate. Can. J. Fish. Aquat. Sci. 54: 2596-2608.

Robbins, J.A. 1981. Sediments of Saginaw Bay, Lake Huron: Elemental composition and accumulation rates. A Final Report to the Environmental Protection Agency, Duluth, MN.

Saether, O.A. 1979. Chironomid communities as water quality indicators. Holarctic Ecology 2:65-74.

Schaeffer, J.S., Diana, J.S., and Haas, R.C. 2000. Effects of long-term changes in the benthic community on yellow perch in Saginaw Bay, Lake Huron. J. Great Lakes Res. 26:340-351.

Schloesser, D.W., Reynoldson, T.B., and Manny, B.A. 1995. Oligochaete fauna of western Lake Erie 1961 and 1982: signs of sediment quality recovery. J. Great Lakes Res. 21:294-306.

Schneider, J.C., Hooper, F.F., and Beeton, A.M. 1969. The distribution and abundance of benthic fauna in Saginaw Bay, Lake Huron. In Proc. $12^{\text {th }}$ Conf. Great Lakes Res., pp. 80-90. Internat. Assoc. Great Lakes Res.

Shannon, E.S., Alexander, H.C., Fetterolf, C.M., and Newton, M.E. 1967. Saginaw Bay Biological Survey, July-August, 1965. Internal Report, Dow Chemical Company, Midland MI.

Simpson, E.H. 1949. Measurement of diversity. Nature 163:688.

Skubinna, J.P., Coon, T.G., and Batterson, T.R. 1995. Increased abundance and depth of submersed macrophytes in response to decreased tubidity in Saginaw Bay, Lake Huron. J. Great Lakes Res. 21:476-478.

Smith, V.E., Lee, K.W., Filkins, J.C., Hartwell, K.W., Rygwelski, K.R., and Townsend, J.M. 1977. Survey of chemical factors in Saginaw Bay (Lake Huron). EPA 600/3-77-125. U. S. Environmental Protection Agency, Duluth, MN.

Stewart, T.W., Miner, J.G., and Lowe, R.L. 1998. Quantifying mechanisms for zebra mussel effects on benthic macroinvertebrates: organic matter production and shell-generated habitat. J. N. Am. Benthol. Soc. 17:81-94.

Stoermer, E.F., and Theriot, E. 1985. Phytoplankton distribution in Saginaw Bay. J. Great Lakes Res. 11: 132-142.

Kreis, R.G., and Ladewske, T.B. 1983. Phytoplankton abundance, species distribution, and community structure in Saginaw Bay and southern Lake Huron in 1980. EPA-600/S3-83-092, USEPA, Large Lakes Research Station, Grosse Isle, MI.

Strayer D.L., and Smith, L.C. 2001. The zoobenthos of the freshwater tidal Hudson River and its response to the zebra mussel (Dreissena polymorpha) invasion. Arch. Hydrobiol. Suppl. 139/1:1-52.

Surber, E.W. 1954. Results of a biological survey of Saginaw Bay, July 16, 17, 1954. Report to the Michigan Water Resources Commission, Lansing, MI.

1955. Results of a biological survey of Saginaw Bay, July 25, 26, 1955. Report to the Michigan Water Resources Commission, Lansing, MI.

Thomas, M., and Haas, R.C. 1997. Changes in the fish community of Saginaw Bay after zebra mussel invasion. Abstract, $40^{\text {th }}$ Conference on Great Lakes Research, Buffalo, NY.

Vanderploeg, H.A., Liebig, J.R., Carmichael, W.W., Agy, M, A., Johengen, T.H., Fahnenstiel, G.L., and Nalepa, T.F. 2001. Zebra mussel (Dreissena polymor- 
pha) selective filtration promoted toxic Microcystis blooms in Saginaw Bay (Lake Huron) and Lake Erie. Can. J. Fish. Aquat. Sci. 58:1208-1221.

Vollenweider, R.A., Munawar, M., and Stadelmann, P. 1974. A comparative review of phytoplankton and primary production in the Laurentian Great Lakes. $J$. Fish. Res. Board Can. 31:739-762.

Wells, L. 1980. Food of alewives, yellow perch, spottail shiners, trout-perch, and slimy and fourhorn sculpins in southeastern Lake Michigan. U. S. Fish Widl. Serv. Tech. Pap. 98.

Winnell, M.W., and Jude, D.J. 1987. Benthic community structure and composition among rocky habitats in the
Great Lakes and Keuka Lake, New York. J. Great Lakes Res. 13:3-17.

Wisenden, P.A., and Bailey, R.C. 1995. Development of macroinvertebrate community structure associated with zebra mussel (Dreissena polymorpha) colonization of artificial substrates. Can. J. Zool. 73:1438-1443.

Wood, L.E. 1964. Bottom sediments of Saginaw Bay, Michigan. J. Sediment. Petrol. 34:173-184.

Submitted: 24 January 2002

Accepted: 2 September 2002

Editorial handling: Trefor Reynoldson 